\title{
Production performance of white shrimp Litopenaeus vannamei with super-intensive culture on different rearing densities
}

\section{Kinerja produksi udang vaname Litopenaeus vannamei pada budidaya super intensif dengan padat penebaran berbeda}

\author{
Andhika Rakhmanda ${ }^{1 *}$, Agung Pribadi $^{2}$, Parjiyo², Bobby Indra Gunawan Wibisono ${ }^{2}$ \\ ${ }^{1}$ Department of Fisheries, Universitas Gadjah Mada, Yogyakarta, Indonesia \\ ${ }^{2} \mathrm{PT}$. Dewi Laut Aquaculture, Garut, West Java, Indonesia \\ *Corresponding author: andhika.rakhmanda@mail.ugm.ac.id
}

(Received December 19, 2017; Accepted November 2, 2020)

\begin{abstract}
This research aimed to evaluate the production performance of white shrimp Litopenaeus vannamei with superintensive culture on different rearing densities. The research was conducted at PT. Dewi Laut Aquaculture, Cikelet, Garut, West Java. As many of 8 ponds were used and divided into 2 groups based on the stock density of shrimp, $550 \mathrm{ind} / \mathrm{m}^{2}$ and $650 \mathrm{ind} / \mathrm{m}^{2}$, and reared for 99 days. The results showed that super-intensive shrimp culture at the density of 550-650 ind/m2 potentially produced shrimp with average body weight ranged from 15.91-19.31 g, survival rate $62.67-87.95 \%$, growth 0.16 to 0.20 g/day, FCR $1.35-1.66$, and productivity reach $5.55-9.19 \mathrm{~kg} /$ $\mathrm{m} 2$. There were no significant differences between the two stocking densities in body weight, growth, and feed conversion performance, while ponds with higher rearing density had better survival and productivity than ponds with lower rearing density. L. vannamei cultured at a density of $650 \mathrm{ind} / \mathrm{m}^{2}$ produces the best performance and most feasible to be applied in super-intensive white shrimp cultivation.
\end{abstract}

Keywords: Litopenaeus vannamei, super-intensive, high-density, production performance

\begin{abstract}
ABSTRAK
Penelitian ini bertujuan untuk mengevaluasi kinerja produksi udang vaname pada sistem super- intensif dengan padat penebaran berbeda. Penelitian dilaksanakan di tambak PT. Dewi Laut Aquaculture, Cikelet, Garut, Jawa Barat, menggunakan 8 petak tambak. Tambak dibagi menjadi 2 kelompok, masing-masing 4 petak tambak dengan padat tebar udang 550 ekor $/ \mathrm{m}^{2}$ dan 4 petak tambak lainnya dengan padat tebar 650 ekor $/ \mathrm{m}^{2}$ dengan masa pemeliharaan 99 hari. Hasil penelitian menunjukkan bahwa budidaya udang vaname pada sistem super-intensif dengan padat tebar 550-650 ekor $/ \mathrm{m}^{2}$ dapat menghasilkan udang dengan bobot rata-rata berkisar antara 15.91-19.31 g, sintasan 62.67$87.95 \%$, pertumbuhan $0.16-0.20$ g/hari, konversi pakan (FCR) 1.35-1.66, dan produktivitas mencapai 5.55-9.19 $\mathrm{kg} / \mathrm{m}^{2}$. Tidak ada perbedaan nyata antara kedua padat penebaran pada kinerja bobot, pertumbuhan harian, dan FCR; sementara tambak dengan kepadatan tinggi memiliki nilai sintasan dan produktivitas yang lebih tinggi dari tambak dengan kepadatan rendah. Padat penebaran 650 ekor $/ \mathrm{m}^{2}$ menghasilkan kinerja produksi terbaik dan paling layak untuk diaplikasikan dalam budidaya udang vaname super-intensif.
\end{abstract}

Kata kunci : Litopenaeus vannamei, padat tebar tinggi, super-intensif, kinerja produksi 


\section{INTRODUCTION}

White shrimp is one of the export commodities with high economical value (Herdianti et al., 2015). Global white shrimp market demand is estimated to reach 5 million tons each year, while the industry is lacking the supply. Global production of shrimp is only 3.6 million tons and 2.37 million tons of it is white shrimp Litopenaeus vannamei which reared in brackish water (FAO GLOBEFISH, 2015). White shrimp production in Indonesia has supported the whole industry of white shrimp culture (Gunarto et al., 2012). White shrimp is a famous species amongst shrimp farmers. It grows faster (Purba, 2012), relatively resistant to disease (Schock et al., 2013; Umiliana et al., 2016), high survival rate, a wide range of salinity tolerance (4-32 g/L) (Maicá et al., 2014), and travels around the water column (Ernawati \& Rochmady, 2017). It also exhibits efficient feeding (Umiliana et al., 2016), can rear in high density (Wasielesky et al., 2013), and high composition of meat (66-68\%) compared to the tiger shrimp (62\%) (Purba, 2012).

The high market demand of vannamei encourages the development of white shrimp culture, one of them is a floating cage net (ZarainHerzberg et al., 2010; Effendi et al., 2016) and super-intensive culture. Various shrimp production is well-developing, starting from the high surface area and low-density culture to technology-based cultures, such as fertilization, feedings trays, and high stock density culture (Wasielesky et al., 2006). Super -culture is the main focus of the future aquaculture using low volume, high stock density (Syah et al., 2017; Krummenauer et al., 2011; Wasielesky et al., 2013), high productivity (Krummenauer et al., 2011; Syah et al., 2017), low wastewater (Syah et $a l ., 2017)$, and equipped with quarantine pond to treat the wastewater (Syah et al., 2017).

Super-intensive shrimp culture is usually conducted in a small container with high density and a short-term rearing period (less than 40 days) (Wasielesky et al., 2006; Maicá et al., 2014). The latter method is combined with the two-step method, i.e. high density in the nursery phase and after several days, the shrimp will be moved to the grow-out phase with lower density (Vinatea et al., 2010; Wasielesky et al., 2013; Schock et al., 2013). White shrimp culture with high density and long rearing period was done by Krummenauer et al. (2011) with 150450 individuals $/ \mathrm{m}^{2}$ for 120 days. A super-intensive culture is expected to increase productivity. However, there is a certain level when the carrying capacity reaches the limit (Syah et al., 2017). An excessive density influences the whole culture system which leads to failure as a consequence of enormous waste. This study was expected to evaluate the production performance of white shrimp in a super-intensive culture with two different densities as a standard to determine an optimal density of white shrimp culture.

\section{MATERIALS AND METHODS}

This study was held in September-December 2016. The shrimp culture was conducted in PT. Dewi Laut Aquaculture, Garut, West Java. It used eight ponds with $400 \mathrm{~m}^{2}$ of average width and $3 \mathrm{~m}$ of depth. The experimental ponds were categorized into two groups, i.e. four ponds with 550 individuals $/ \mathrm{m}^{2}$ (T550) and four ponds with 650 individuals $/ \mathrm{m}^{2}$ (T650). The result by Krummenaur et al. (2011) was used to determine the treatments in this study. It was possible to increase the density beyond 450 individuals $/ \mathrm{m}^{2}$ due to the sufficient result by Krummenaur et al. (2011).

The pond construction was covered by HDPE plastic with $0.75 \mathrm{~mm}$ of thickness. It was also furnished with a central drain, one blower with 7.5 horsepower (HP), and four paddle wheel with $1 \mathrm{HP}$ each (Figure 1). A $1 \mathrm{HP}$ of paddle wheel facilitates $16 \mathrm{~kg}$ of feeding per day with maintaining dissolved oxygen content amongst $3 \mathrm{mg} / \mathrm{L}$ and targeted biomass around 550-600 $\mathrm{kg}$ (Hopkins et al., 1991). The water level was filled up to $2.5 \mathrm{~m}$ depth, followed by $15 \mathrm{mg} / \mathrm{L}$ of trichloroisocyanuric acid (TCCA), $25 \mathrm{mg} / \mathrm{L}$ of saponin, $1 \mathrm{mg} / \mathrm{L} \mathrm{ZA}$ fertilizer, $1.5 \mathrm{mg} / \mathrm{L}$ of molasse, $5 \mathrm{mg} / \mathrm{L}$ of dolomite, and $0.1 \mathrm{~g} / \mathrm{m}^{2}$ of commercial probiotics (Bacillus sp., Thiobacillus sp., Nitrosomonas sp., and Nitrobacter sp.) to grow plankton and form flocs for 12 days. Particularly, the probiotics were delivered every two weeks during the culture.

The tested seed used in this study was specific pathogen-free (SPF) post larvae 9 from Lampung Province. They were reared in the pond for 100 days based on the treatment using a semifloc system. The tested post-larvae were fed using crumble feed with $40 \%$ of protein content in the initial phase, then changed to a pellet with $36 \%$ of protein content after 20 days. It was based on the standard of white shrimp farming. In the first month of study, the blind feeding method was applied. Blind feeding is established according 
to survival and average weight estimation, also feeding rate (15\% of total biomass). The percentage was declined to $5 \%, 4 \%$, and $3 \%$ for the second, third, and fourth month, respectively. Feeding frequency was carried out six times a day. During the rearing period, water discharge and siphoning were completed regularly to eliminate uneaten feed and organic waste on the bottom of the pond. Partial harvest was conducted as many as $25 \%$ of the biomass on day 60 dan 75 . On the contrary, the total harvest was done on day 99.

\section{Tested parameters}

The tested parameters consisted of average body weight $(\mathrm{ABW})$, average daily weight (ADG), survival, feed conversion ratio (FCR), and productivity. ABW and ADG were measured regularly after 30 days of rearing by collecting 30-40 shrimp in each pond every seven days. Survival, FCR, and productivity were calculated at the end of the study. The following formulas are used to calculate ABW, ADG, survival, FCR, and productivity (Maicá et al., 2014).

\section{Average body weight ( $A B W$ )}

$\mathrm{ABW}$ is a ratio between individual bodyweight and population weight. It is calculated using the following formula.

$$
\mathrm{ABW}=\frac{\sum \text { shrimp weight }(\mathrm{g})}{\sum \text { shrimp population }(\mathrm{g})}
$$

Average daily gain $(A D G)$

ADG is daily weight addition in a certain time. It is calculated using the formula below.

$$
\mathrm{ADG}=\frac{\mathrm{ABW}_{\mathrm{t}}-\mathrm{ABW}_{0}}{\mathrm{H}}
$$

$\mathrm{ABW}_{\mathrm{t}}=$ final average weight $(\mathrm{g})$

$\mathrm{ABW}_{0}=$ initial average weight $(\mathrm{g})$

$\mathrm{H} \quad=$ rearing period (day)
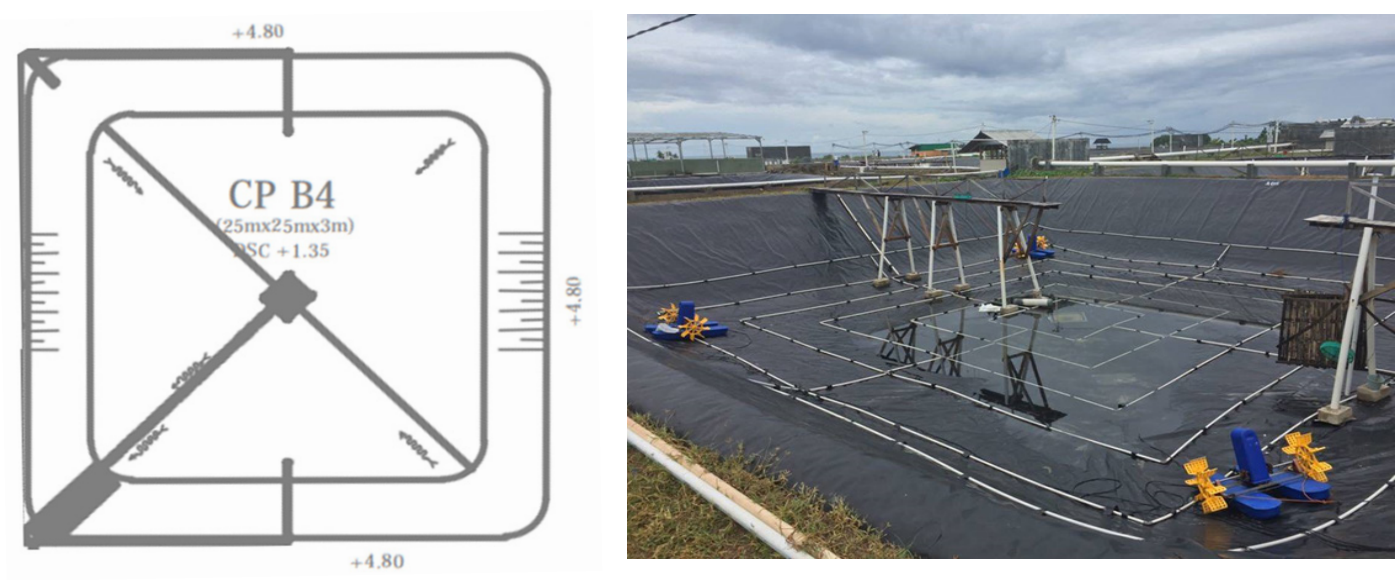

Figure 1. Experimental pond construction

\begin{tabular}{|c|c|c|c|c|}
\hline No & Pond code & Wide $\left(\mathrm{m}^{2}\right)$ & Population (individual) & Density (ind $/ \mathrm{m}^{2}$ ) \\
\hline \multicolumn{5}{|c|}{ Group I (T550) } \\
\hline 1 & $\mathrm{~A} 2$ & 407 & 222,528 & 547 \\
\hline 2 & $\mathrm{~A} 3$ & 410 & 222,528 & 543 \\
\hline 3 & A5 & 406 & 226,452 & 558 \\
\hline 4 & $\mathrm{~A} 10$ & 408 & 225,122 & 552 \\
\hline & Average & 408 & 224,158 & $550 \pm 6.49$ \\
\hline \multicolumn{5}{|c|}{ Group II (T650) } \\
\hline 1 & $\mathrm{~A} 2$ & 395 & 256,891 & 650 \\
\hline 2 & $\mathrm{~A} 3$ & 410 & 266,585 & 650 \\
\hline 3 & A5 & 395 & 257,580 & 652 \\
\hline 4 & A 10 & 437 & 282,384 & 646 \\
\hline & Average & 409 & 265,860 & $650 \pm 2.50$ \\
\hline
\end{tabular}

Table 1. Shrimp population and density each ponds. 


\section{Survival rate}

Survival is the percentage of the survived population at the end of the study. It was calculated by dividing the final population and initial population.

$$
\mathrm{SR}(\%)=\frac{\mathrm{Nt}}{\mathrm{No}} \times 100
$$

$\mathrm{SR}=$ Survival $(\%)$

$\mathrm{Nt}=$ Final population

No = Initial population

\section{Feed conversion ratio (FCR)}

FCR is a mathematical relationship between total feed and biomass gained by consuming it. It was calculated using the following formula.

\section{Productivity}

In this study, productivity was measured based on a unit of pond-wide. The following formula was used to determine productivity. Water quality parameters in this study were temperature, dissolved oxygen (DO), $\mathrm{pH}$, salinity, total ammonia nitrogen (TAN), nitrite $\left(\mathrm{NO}_{2}^{-}\right)$, nitrate $\left(\mathrm{NO}_{3}{ }^{-}\right)$, phosphate $\left(\mathrm{PO}_{4}\right)$, and total organic matter (TOM). Temperature, $\mathrm{DO}$, and $\mathrm{pH}$ was measure daily every morning, afternoon, and evening. Meanwhile, salinity, TAN, phosphate, and TOM were measured every week, twice a day.

\section{Data analysis}

The growth parameters were analyzed statistically using Repeated Measures ANOVA through IBM SPSS Statistics 20 to determine the significant difference amongst treatments. The rest of the data were described descriptively to discover the biological response of the white shrimp and characteristics of the aquatic environment.

\section{RESULTS AND DISCUSSION}

The T550 treatment resulted in survival ranged from $62.67-87.95 \%$ and ABW was 15.91-19.31 $\mathrm{g}$. The ADG, FCR, and productivity ranged from $0.16-0.20 \mathrm{~g} / \mathrm{day}, 1.35-1.66$, and $5.55-7.54 \mathrm{~kg} /$ $\mathrm{m}^{2}$, respectively. Meanwhile, the T650 treatment presented 79.97-87.34\% of survival, 16.50-17.91 $\mathrm{g}$ of ABW, and 0.17-0.19 g/day of ADG. FCR and productivity ranged from $1.38-1.49$ and $7.87-$ $9.19 \mathrm{~kg} / \mathrm{m}^{2}$ (Table 2). Those results were in line with Krummenauer et al. (2011) who conducted white shrimp culture in a biofloc system with 150,300 , and $450 \mathrm{ind} / \mathrm{m}^{2}$ of density for 120 days. He reported that the survival was around 75-92 \%, ABW was 9-16.8 g, ADG ranged from $0.07-0.13 \mathrm{~g} /$ day, FCR extended in 1.29-2.41, and productivity differed between $2.15-4.09 \mathrm{~kg} / \mathrm{m}^{2}$.

The water quality parameter indicated a supportive environment condition to the white shrimp. There was no intense difference amongst the treatment. The temperature was relatively $26-$ $32^{\circ} \mathrm{C}$, dissolved oxygen was $4.0-8.3 \mathrm{mg} / \mathrm{L}$, and $\mathrm{pH}$ was 7.3-8.9. Total ammonia nitrogen, nitrite, nitrate, phosphate, and organic matter extended from $0.5-5 \mathrm{mg} / \mathrm{L}, 0.1-25 \mathrm{mg} / \mathrm{L}, 1-150 \mathrm{mg} / \mathrm{L}$, $0.3-3 \mathrm{mg} / \mathrm{L}$, and $38-126 \mathrm{mg} / \mathrm{L}$, respectively (Table 3).

Table 2. White shrimp production in super intensive system

\begin{tabular}{|c|c|c|c|c|c|c|c|}
\hline $\begin{array}{l}\text { Density } \\
\left(\text { ind } / \mathrm{m}^{2}\right)\end{array}$ & $\begin{array}{l}\text { Pond } \\
\text { ID }\end{array}$ & Biomass (kg) & SR (\%) & $\mathrm{ABW}(\mathrm{g})$ & ADG $(g)$ & FCR & $\begin{array}{c}\text { Productivity } \\
\left(\mathrm{kg} / \mathrm{m}^{2}\right)\end{array}$ \\
\hline \multirow{4}{*}{550} & A2 & $3,069.11$ & 76.60 & 19.31 & 0.20 & 1.35 & 7.54 \\
\hline & A3 & $2,889.08$ & 73.12 & 19.24 & 0.19 & 1.45 & 7.05 \\
\hline & A5 & $2,255.03$ & 62.67 & 17.29 & 0.17 & 1.66 & 5.55 \\
\hline & A10 & $2,924.08$ & 87.95 & 15.91 & 0.16 & 1.36 & 7.17 \\
\hline Average & & $\begin{array}{c}2,784.33 \pm \\
361.37^{\mathrm{a}} \\
\end{array}$ & $\begin{array}{c}75.09 \pm \\
10.42^{\mathrm{a}}\end{array}$ & $17.93 \pm 1.64^{\mathrm{a}}$ & $0.18 \pm 0.02^{\mathrm{a}}$ & $1.45 \pm 0.14^{\mathrm{a}}$ & $6.83 \pm 0.87^{a}$ \\
\hline \multirow{4}{*}{650} & B4 & $3,109.53$ & 79.97 & 16.94 & 0.18 & 1.46 & 7.87 \\
\hline & B7 & $3,400.39$ & 80.22 & 17.72 & 0.19 & 1.43 & 8.29 \\
\hline & B8 & $3,629.34$ & 87.34 & 17.91 & 0.18 & 1.38 & 9.19 \\
\hline & $\mathrm{B} 10$ & $3,574.08$ & 85.04 & 16.50 & 0.17 & 1.49 & 8.18 \\
\hline Average & & $\begin{array}{c}3,428.34 \pm \\
233.85^{\mathrm{b}}\end{array}$ & $83.14 \pm 3.64^{b}$ & $17.27 \pm 0.66^{\mathrm{a}}$ & $0.18 \pm 0.01^{\mathrm{a}}$ & $1.44 \pm 0.05^{\mathrm{a}}$ & $8.38 \pm 0.57^{b}$ \\
\hline
\end{tabular}

Note: Different superscript letter in the same column indicates significant different $(\mathrm{P}<0.05)$. 
According to Table 4, it was clearly described that there was no significant difference amongst treatment in ABW, ADG, and FCR $(\mathrm{P}>0.05)$. On the contrary, survival dan productivity indicated a significant difference amongst treatments $(\mathrm{P}<0.05)$. The T550 treatment presented a slightly greater result compared to the T650. Even though, there was no significant result on both $\mathrm{ABW}$ and ADG (Table 4). A tolerable environment was assumed to support the white shrimp culture.

Figure 2 explained that the daily growth of the white shrimp was relatively identical until day 40 . Some sort of contrast were started to appear after day 40 that leads to a greater result in T550. The growth of white shrimp was straightly affected by the density. When the density went higher, the growth was likely lessened. Several former studies support the result, i.e. Balakrishnan et al. (2011), Krishna et al. (2015), Budiardi et al. (2005), and Krummenauer et al. (2011).

Both treatments presented greater ADG (0.18 $\pm 0.02 \mathrm{~g} /$ day) compared to Krummenauer et al. (2011) $(0.12,0.13$, and $0.07 \mathrm{~g} /$ day) with 150,300 , and $450 \mathrm{ind} / \mathrm{m}^{2}$ of density. A similar result was described by Syah et al. (2017) $(0.20 \pm 0.01 \mathrm{~g} /$ day) who reared white shrimp in 700,1000 , and
$1200 \mathrm{ind} / \mathrm{m}^{2}$ of density. Those results indicated that white shrimp was relatively tolerant towards high density. Budiardi et al. (2005) stated that the density will affect the competition amongst individuals, in terms of area, food, and oxygen. However, the ability of white shrimp to utilize the entire water column, tolerable water condition, and adequate nutrition supply also positively contributed to weight gain without being disturbed by the density (Syah et al., 2017). Wasielesky et al. (2013) reported that the aborted white shrimp for 35 days which reared in $1500-6000 \mathrm{ind} / \mathrm{m}^{2}$ reported no significant weight gain compared to the $300 \mathrm{ind} / \mathrm{m}^{2}$ of density.

The T550 treatment produced lower survival than the T650 treatment. This opposed the result by Budiardi et al. (2005), Krummenauer et al. (2011), Krishna et al. (2015), and Syah et al. (2017) who confirmed that higher density would lead to lower survival. Nevertheless, diverse survival could appear as well, e.g. Ernawati and Rochmady (2017). They used various densities, i.e. $9,14,19 \mathrm{ind} / \mathrm{container}$ and the survival was $70.37 \%, 78.57 \%$, and $74.27 \%$, respectively. Ernawati and Rochmady (2017) suggested that the highest survival was considered as the

Table 3. Water quality result.

\begin{tabular}{|c|c|c|c|c|}
\hline \multirow{2}{*}{ Water quality parameter } & \multicolumn{2}{|c|}{ Treatment } & \multirow{2}{*}{ Threshold } & \multirow{2}{*}{ Reference } \\
\hline & T550 & $\mathrm{T} 650$ & & \\
\hline Temperature $\left({ }^{\circ} \mathrm{C}\right)$ & $26-32$ & $26-32$ & $20-32$ & González et al., 2010 \\
\hline Dissolved Oxygen (mg/L) & $4.00-6.80$ & $4.0-8.3$ & $\geq 4$ & Cobo et al., 2014 \\
\hline $\mathrm{pH}$ & $7.5-8.8$ & $7.3-8.9$ & $6-9$ & Boyd, 1989 \\
\hline Salinity $(\mathrm{g} / \mathrm{L})$ & $21-26$ & $21-26$ & $20-45$ & Chong-Robles et al., 2014 \\
\hline \multirow[t]{2}{*}{ TAN (mg/L) } & $0.5-5$ & $0.5-5$ & $\leq 13.2$ & Cobo et al., 2014 \\
\hline & & & $\leq 28.2$ & Schuler et al., 2010 \\
\hline Nitrite (mg/L) & $0.1-25$ & $0.1-25$ & $\leq 163.3$ & Schuler et al., 2010 \\
\hline Nitrate $(\mathrm{mg} / \mathrm{L})$ & $1-150$ & $1-125$ & $\leq 220$ & Khun et al., 2010 \\
\hline Phosphate (mg/L) & $0.3-3$ & $0.3-3$ & $\leq 390.55$ & Na et al., 2009 \\
\hline Total organic matter $(\mathrm{mg} / \mathrm{L})$ & $38-126$ & $25-125$ & $<500$ & Gaona et al., 2011 \\
\hline
\end{tabular}

Table 4. Production performance of white shrimp with different densities.

\begin{tabular}{ccc}
\hline Production performance & \multicolumn{2}{c}{ Treatment } \\
\cline { 2 - 3 } & 7550 & T650 \\
\hline Survival rate/SR $(\%)$ & $17.99 \pm 10.42^{\mathrm{a}} \pm 1.64^{\mathrm{a}}$ & $83.14 \pm 3.64^{\mathrm{b}}$ \\
Average body weight/ABW $(\mathrm{g})$ & $0.18 \pm 0.02^{\mathrm{a}}$ & $17.27 \pm 0.66^{\mathrm{a}}$ \\
Average daily growth/ADG $(\mathrm{g} / \mathrm{day})$ & $1.45 \pm 0.14^{\mathrm{a}}$ & $0.18 \pm 0.01^{\mathrm{a}}$ \\
Feed conversion ratio/FCR & $6.83 \pm 0.87^{\mathrm{a}}$ & $1.44 \pm 0.05^{\mathrm{a}}$ \\
Productivity $\left(\mathrm{kg} / \mathrm{m}^{2}\right)$ & $8.38 \pm 0.57^{\mathrm{b}}$ \\
\hline
\end{tabular}

Note: Different superscript letter in the same row indicates significant different $(\mathrm{P}<0.05)$. 
optimum survival because no food and movement competition triggered cannibalism amongst individuals. In this study, the T650 treatment was considered as an acceptable density for white shrimp culture. Also, the dissolved oxygen and nitrate in the $\mathrm{T} 650$ treatment were slightly better.

The FCR in this study did not differ significantly $(\mathrm{P}>0.05)$ amongst treatments (Table 4). It was different from Budiardi et al. (2005) who reported that shrimp that culture in low density $\left(72-73 \mathrm{ind} / \mathrm{m}^{2}\right)$ showed lower FCR compared to the higher density $\left(93-105 \mathrm{ind} / \mathrm{m}^{2}\right)$. However, various FCR was also shown in several studies, such as Krummenauer et al. (2011) with 150,300 , and $450 \mathrm{ind} / \mathrm{m}^{2}$ of stocking density and Syah et al. (2017) with 750, 1000, and 1250 ind/ $\mathrm{m}^{2}$. Live feed supply tends to decrease when the density grows higher so that shrimp will rely on the artificial feed even more (Budiardi et al., 2008; Mangampa \& Suwoyo, 2010). As a result, shrimp culture with high density is required to estimate the population accurately. It is essential to avoid excessive feeding that possibly leads to high FCR.

Productivity is the harvested biomass in a certain wide unit. Productivity increases along with biomass. In this study, the T650 treatment showed greater productivity compared to the T550. On the contrary, Budiardi et al. (2005) reported that lower density showed higher productivity. In this case, the T650 treatment still presented excellent productivity, so that the biomass was high as well. Fleckenstein et al. (2020) stated that stocking density directly affected shrimp production significantly. It was possible because the water quality parameter in the T650 still supported the shrimp culture system, especially dissolved oxygen, temperature, $\mathrm{pH}$, and salinity (Table 3 ). It showed that the productivity strongly increased along with the density continuously until a certain level of carrying capacity in an aquatic environment.

Ammonia-nitrogen content and organic matter in both treatments were relatively high. Although it was tolerable for shrimp culture (Cobo et al., 2014; Schuler et al., 2010). Ammonia is a toxic output of organic matter demolishing. Ammonia toxicity declines when the dissolved oxygen raising (Barbieri, 2010). A high level of ammonia is distinctly influenced by the density due to the high waste of feces and uneaten feed. Superintensive culture often faces eutrophication due to excessive nutrient and organic waste (Nguyen et al., 2019; Nguyen et al., 2020). Nevertheless, nitrification was run by the bacteria to maintain the ammonia-nitrogen content. Nitrosomonas sp. and Nitrobacter sp. oxidated ammonia-nitrogen, so that it changed into nitrite and nitrate. Nitrate is the final result of nitrification which later will be benefited by phytoplankton (Herdianti et al., 2015).

Thereafter, high density demands more feed. Excessive feed triggers higher pollutants, e.g. uneaten feed and metabolic waste (Budiardi et $a l ., 2005)$. Organic matter accumulation produces ionic iron, hydrogen sulfide, and reduced compounds, which are lethal for shrimp Boyd (1989). In line with Budiardi et al. (2005), Khoa et al. (2020) stated that high density induced a higher concentration of microbes due to the abundant nutrition in the water. Dissolved oxygen demand

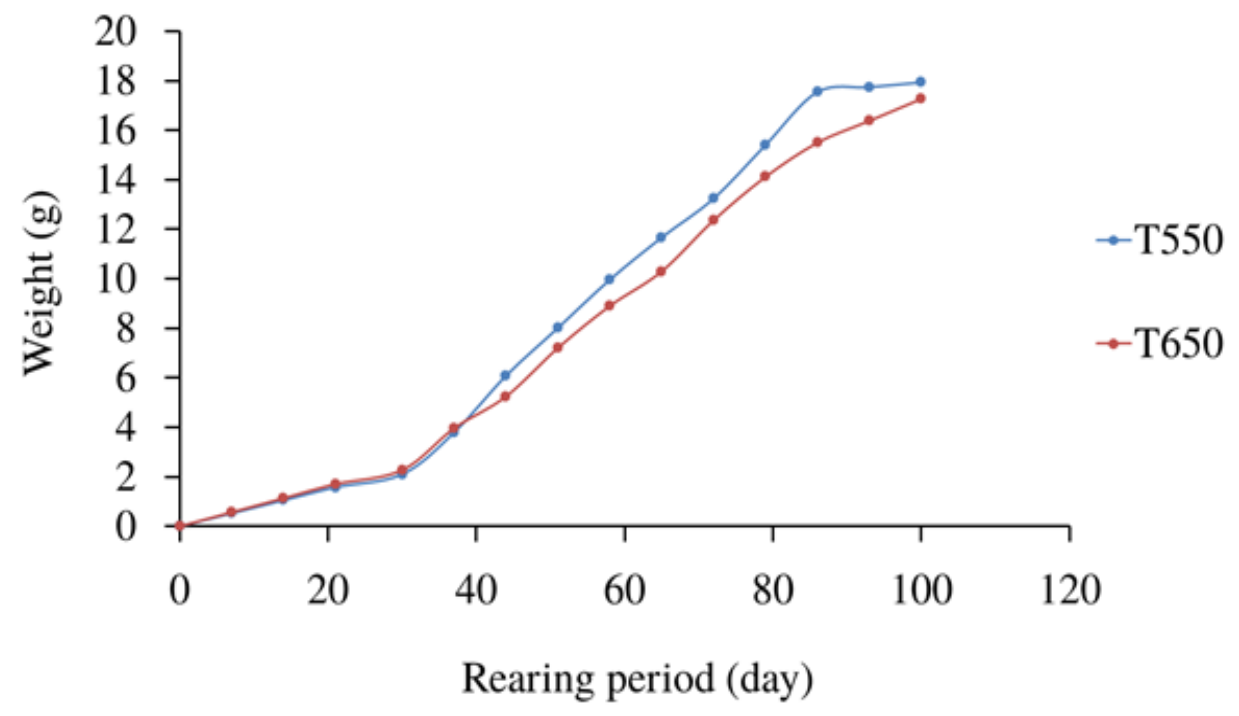

Figure 2. White shrimp growth in various density 
and suspended solid will elevate and the turbidity will also affect shrimp growth (Fleckenstein et al., 2020). However, the water quality results in this study were kept in tolerable range, so that eutrophication in the pond ecosystem did not influence shrimp survival, growth, and biomass significantly (González et al., 2010; Cobo et al., 2014; Boyd, 1989; Chong-Robles et al., 2014; Schuler et al., 2010; Khun et al., 2010; Na et al., 2009; Gaona et al., 2011). Gaona et al. (2011) declared that organic matter can be reduced when the culture system is well-managed. A decreased organic waste will lead to the excellent water condition. Furthermore, shrimp culture with a greater growth will be fully supported (Gaona et al., 2011). Overall, we can conclude that high-density shrimp culture was applicable with advanced environmental management.

\section{CONCLUSION}

There was no significant difference amongst treatments in terms of ABW, ADG, and FCR. On the contrary, survival and productivity showed a significant result in the T650 treatment. We can conclude that the T650 treatment was considered applicable in super-intensive shrimp culture.

\section{ACKNOWLEDGMENT}

This study was funded by PT. Dewi Laut Aquaculture. The authors are also immensely grateful to Rizal Mallarangeng, Agus Suryawinadi, and Wayan Agus Edhy for support, advice, and guidance that greatly improved this study.

\section{REFERENCES}

Balakrishnan G, Peyail S, Ramachandran K, Theivasigamani A, Savji KA, Chokkaiah M, Nataraj P. 2011. Growth of cultured white leg shrimp Litopenaus vannamei (Boone, 1931) in different stocking density. Advances in Applied Science Research 2: 107-113.

Barbieri E. 2010. Acute toxicity of ammonia in white shrimp (Litopenaeus schmitti) (Burkenroad, 1936, Crustacea) at different salinity levels. Aquaculture 306: 329-333.

Boyd CE. 1989. Water quality manajemen and aeration in shrimp farming. Albama, USA: Auburn University.
Budiardi T, Muzaki A, Utomo NBP. 2005. White shrimp Litopenaeus vannamei production on different rearing densities in biocrete pond. Jurnal Akuakultur Indonesia 4: 109-113.

Budiardi T, Muluk C, Widigdo B, Praptokardiyo K, Soedharma D. 2008. Level of feed utilization and suitability of water quality and estimation of vaname shrimp (Litopenaues vannamei) (Boone, 1931) growth and production at intensive system. Jurnal Ilmu-ilmu Perairan dan Perikanan Indonesia 15: 109-116.

Chong-Robles J, Charmantier G, Boulo V, Lizarraga-Valdez J, Enriquez-Paredes LM, Giffard-Mena I. 2014. Osmoregulation pattern and salinity tolerance of the white shrimp Litopenaeus vannamei (Boone, 1931) during post-embryonic development. Aquaculture 422423: 261-267.

Cobo ML, Sonnenholzner S, Wille M, Sorgeloos P. 2014. Ammonia tolerance of Litopenaeus vannamei (Boone) larvae. Aquaculture Research 45: 470-475.

Effendi I, Suprayudi MA, Surawidjaja EH, Supriyono E, Zairin MJ, Sukenda. 2016. Production performance of white shrimp Litopenaeus vannamei under sea floating net cages with biofloc and periphyton juvenile. AACL Bioflux 9: 823-832.

Ernawati, Rochmady. 2017. Effect of fertilization and density on the survival rate and growth of post-larva of shrimp vaname Litopenaues vannamei. Jurnal Akuakultur, Pesisir dan Pulau-Pulau Kecil 1: 1-10.

FAO GLOBEFISH. 2015. Shrimp. http://www. globefish.org/shrimp-may-2015.html. [12 July 2015].

Fleckenstein LJ, Kring NA, Tierney TW, Fisk JC, Lawson BC, Ray AJ. 2020. The effects of artificial substrate and stocking density on Pacific white shrimp Litopenaeus vannamei performance and water quality dynamics in high tunnel-based biofloc systems. Aquaculture Engineering 90: 102093.

Gaona CAP, Poersch LH, Krummenauer D, Foes GK, Wasielesky WJ. 2011. The effect of solids removal on water quality, growth and survival of Litopenaeus vannamei in a biofloc technology culture system. International Journal of Recirculating Aquaculture 12: 5473.

González RA, Diaz F, Licea F, Re AD, Sánchez LN, Garcia-Esquivel Z. 2010. Thermal 
preference, tolerance and oxygen consumption of adult white shrimp Litopenaeus vannamei (Boone) exposed to different acclimation temperatures. Journal of Thermal Biology 35: 218-224.

Gunarto, Suwoyo HS, Tampangallo BR. 2012. Intensive of white shrimp, L. vannamei pond culture with biofloc systems in brackishwater pond. Jurnal Riset Akuakultur 7: 393-405.

Herdianti L, Soewardi K, Hariyadi S. 2015. Effectiveness on the use of bacteria for improvement of white shrimp Litopenaeus vannamei super intensive culture media. Jurnal Ilmu Pertanian Indonesia 20: 265-271.

Hopkins JS, Stokes AD, Browdy CL, Sandifer PA. 1991. The relationship between feeding rate, paddle wheel aeration rate and expected dawn dissolved oxygen in intensive shrimp ponds. Aquaculural Engineering 10: 281-290.

Khoa TND, Tao CT, Khanh LV, Hai TN. 2020. Super-intensive culture of white leg shrimp Litopenaeus vannamei in outdoor biofloc systems with different sunlight exposure levels: Emphasis on commercial applications. Aquaculture 524: 735277.

Khun DD, Smith SA, Boardman GD, Angier MW, Marsh L, Flick GJ. 2010. Chronic toxicity of nitrate to Pacific white shrimp, Litopenaeus vannamei: Impacts on survival, growth, antennae length, and pathology. Aquaculture 309: 109-114.

Krishna PV, Prakash BK, Kumar VH, Prabhavathi K. 2015. Growth, survival and production of Pacific white shrimp Litopenaeus vannamei at different stocking densities under semiintensive culture system in Andhra Pradesh. International Journal of Advanced Research 3: 446-452.

Krummenauer D, Peixoto S, Cavalli RO, Poersch LH, Wasielesky WJ. 2011. Superintensive culture of white shrimp, Litopenaeus vannamei, in a biofloc technology systems in Southern Brazil at different stocking densities. Journal of the World Aquaculture Society 42: 726-733.

Maicá PF, de Borba MR, Martins TG, Wasielesky WJ. 2014. Effect of salinity on performance and body composition of Pacific white shrimp juveniles reared in a super-intensive system. Revista Brasileira de Zootecnia 43: 343-350.

Mangampa M, Suwoyo HS. 2010. Vannamei shrimp Litopenaeus vannamei intensive culture technology using shrimp. Jurnal Riset Akuakultur 5: 351-361.

$\mathrm{Na}$ Y, Shimei C, Erchao L, Jiayan C, Liqiao C. 2009. Tolerance of Physocypria kraepelini (Crustacean, Ostracoda) to water-borne ammonia, phosphate and $\mathrm{pH}$ value. Journal of Environmental Sciences 21: 1575-1580.

Nguyen TAT, Nguyen KAT, Jolly C. 2019. Is super-intensification the solution to shrimp production and export sustainability?. Sustainability 11: 5277.

Nguyen KAT, Nguyen TAT, Jolly C, Nguelifack BM. 2020. Economic efficiency of extensive and intensive shrimp production under conditions of disease and natural disaster risks in Khánh Hòa and Trà Vinh Provinces, Vietnam. Sustainability 12: 2140.

Purba CY. 2012. The performance of growth, survival, and nutritional content of white shrimp larvae Litopenaeus vannamei through feeding of local artemia enriched with diatomic cells. Journal of Aquaculture Management and Technology 1: 102-115.

Schock TB, Duke J, Goodson A, Weldon D, Brunson J, Leffler JW, Bearden DW. 2013. Evaluation of pacific white shrimp Litopenaeus vannamei health during superintensive aquaculture growout using NMR-based metabolomics. PLOS ONE 8: 1-12.

Schuler DJ, Boardman GD, Kuhn DD, Flick GJ. 2010. Acute toxicity of ammonia and nitrite to Pacific white shrimp, Litopenaeus vannamei, at low salinities. Journal of The World Aquaculture Society 41: 438-446.

Syah R, Makmur, Fahrur M. 2017. The Litopenaeus vannamei aquaculture under high stocking density. Media Akuakultur 12: 19-26.

Thakur DP, Lin CK. 2003. Water quality and nutrient budget in closed shrimp Penaeus monodon culture systems. Aquacultural Engineering 27: 159-176.

Umiliana M, Sarjito, Desrina. 2016. Effect of salinity to infectious myonecrosis virus (IMNV) pada on white shrimp Litopenaeus vannamei (Boone, 1931). Journal of Aquaculture Management and Technology 5: 73-81.

Vinatea L, Gálvez AO, Browdy CL, Stokes A, Venero J, Haveman J, Lewis BL, Lawson A, 
Shuler A, Leffler JW. 2010. Photosynthesis, water respiration and growth performance of Litopenaeus vannamei in a super-intensive raceway culture with zero water exchange: Interaction of water quality variables. Aquacultural Engineering 42: 17-24.

Wasielesky WJ, Atwood H, Stokes A, Browdy CL. 2006. Effect of natural production in a zero exchange suspended microbial floc based super-intensive culture system for white shrimp Litopenaeus vannamei. Aquaculture 258: 396-403.
Wasielesky WJ, Froes C, Foes G, Krummenauer D, Lara G, Poersch L. 2013. Nursery of Litopenaeus vannamei reared in a biofloc system: the effect of stocking densities and compensatory growth. Journal of Shellfish Research 32: 799-806.

Zarain-Herzberg M, Fraga I, HernandezLlamas A. 2010. Advances in intensifying the cultivation of the shrimp Litopenaeus vannamei in floating cages. Aquaculture 300: 87-92. 